\title{
Tibetan Drum and Trumpet.
}

\section{A. R. Wright}

To cite this article: A. R. Wright (1904) Tibetan Drum and Trumpet., Folklore, 15:3, 333-334, DOI: $10.1080 / 0015587 X .1904 .9719415$

To link to this article: http://dx.doi.org/10.1080/0015587X.1904.9719415

册 Published online: 06 Feb 2012.

Submit your article to this journal

Џ Article views: 3

Q View related articles $₫$ 
everything for us, and who are the owners of our souls and lives, keep us safe with you."

The mantra or formula appropriate to the contained prayers must he repeated before a wheel is turned, and also at the end of the rotation, or else no merit will be gained. The mantra should also be repeated as often as possible while the turning is going on, and the faster the turning the greater the merit. It is also necessary that the wheel shall be turned only in the direction in which a person would go keeping his right side always to the axle. To turn in the reverse direction is to undo all that has been previously done by a right turning.

The smaller prayer-wheel, mounted on a long wooden handle and seen to the left of the Plate, is for hand use, and is kept in motion with very little effort by the help of the chain and weight. $A$ hook and chain are also provided for the suspension of the wheel, which contains the usual formula, and has embossed on it the "eight glorious emblems" found in Buddha's footprints, viz. the golden fish, umbrella, conch-shell trumpet of victory, lucky diagram, victorious banner, vase, lotus, and wheel.

A. R. WRIGIT.

\section{Tiretan Drum and Trumpet.}

\section{(Exhibited at Meeting of Society. See Plate VII. and p. 243.)}

Tuk object to the right of Plate VII. is a drum made of the caps of two human skulls secured together at their apices, and with their bases covered by human skin. The drum is beaten by jerking it from one side to the other by the supporting band, so that the two hanging leather bobs strike the skin coverings.

The other object shown is a kain-lin, or trumpet made of a human thigh-bone, the lower part of which is covered with human skin. Such a trumpet "is sometimes encased in brass, with a wide copper flanged extremity, on which are figured the three eyes and nose of a demon, the oval open extremity being the demon's mouth. In the preparation of these thigh-bone trumpets the bones of criminals or those who have died by violence are preferred, and an elaborate incantation is done, part of which consists in the IAma eating a portion of the skin of the bone; otherwise its blast would not be sufficiently powerful to summon 
the demons." (Waddell's The Buddhism of Tibet, p. 300.) A trumpet of this kind is blown at the beginning of a mystery play. A Lama with a thigh-bone trumpet also walks before a corpse on its way to burial or cremation, holding the end of a white band secured to the corpse, and by the use of his trumpet attracts the soul and guides it in the right direction.

Both the objects illustrated are placed upon temple altars. Cannibalism is stated by the Tibetans themselves to have been their ancient custom, and is alleged still to linger in very remote districts. The use of the implements described may be a vestige of the practice.

A. R. WRIGHT.

The Shwe-hmu, or Burmese Tax-Gatherer. (Communicated through Mr.J. G. Frazer.)

WHEN I was stationed at Banmauk in the Katha district of Upper Burma in 1900 , I heard of the following custom, which was practised previous to the annexation of Upper Burma in $\mathbf{r} 886$, and perhaps up to the time of the Wuntho expedition, which resulted in the annexation of the Wuntho state about 1892 . The people who practised it are a race of mixed origin known as the Ganans or Ganan-kadus. They inhabit the valley in which the Mfu rises (a tributary of the Irrazuaddy), about twenty-five miles in length and perhaps eight in breadth, about midway between the Chindzuin and the Irrazeaddy rivers, between $24^{\circ}$ and $25^{\circ}$ lat. and $95^{\circ}-96^{\circ}$ long. Their chief villages (marked on a large-scale map) are HIanyaze and Shwegyaung. Before the annexation these people were governed by their own Shwe-hmu (lit. gold (tad') payer), or head-man. They were subject to the king of Burma and an officer of his who lived some sixty miles (by road) to the southeast, and interfered with Ganan little if at all.

A Shroe-hmu's main official duty would be to collect the lump sum assessed on his district as taxation, and pay it in to the king's officer. He would act in a rough sort of way as judge or magis. trate in his circle, and would practically settle all disputes and punish malefactors in an out-of-the-way place like Ganan. I am not clear whether there were two Shwe-hmus or only one. The Ganan-Kadus are said to be divided into the Ganan-mas and the 